\title{
Structural Equation Analysis of Social Support, Impaired Fasting Glucose, and Type 2 Diabetes
}

\author{
Yun-Jung Kang ${ }^{1, \dagger ;}$, Sang-Nam Park ${ }^{2, *}$ and Ki Nam Yoon ${ }^{3, *}$ \\ ${ }^{1}$ Department of Clinical Laboratory Science, Sang-ji University, Wonju 26339, Korea \\ ${ }^{2}$ Department of Clinical Laboratory Science, Kyungdong University, Wonju 26495, Korea \\ ${ }^{3}$ Department of Clinical Laboratory Science, Ansan University, Ansan 15651, Korea
}

This study is to identify how the social support influences the impaired fasting glucose and type 2 diabetes as structural equation analysis reflects the health behavior and psychological path. It investigates participants who give consents to participate in the Korean Health Examine Cohort (KOEX), which collects surveys and biological samples at eight university hospitals nationwide. Of the 53,767 adults over 30 years of age enrolled in the 2nd to 7th KOEX study from 2004 to 2010 (1st to 7th), 18,618 participants with a history of chronic diseases related to type 2 diabetes, the main variable, were excluded. The number of participants were 34,316 with enough data on social support and diabetes, which are the main variables. The results show that social support affects health behaviors and lowers fasting blood sugar. Therefore, not only the management of risk factors of individuals, but also the practice of healthy behavior with the attention of social relations such as social support, etc., can prevent type 2 diabetes.

Key Words: Social support, Impaired fasting glucose, Type 2 diabetes, Structural equation analysis

\section{서 론}

우리나라는 1970년대부터 급속한 경제발전과 의료기술 의 발달과 생활수준의 향상으로 인해 만성질환이 두드러 지게 증가하는 경향을 보이고 있다(Ryu et al., 2006). 만성 질환은 개인의 신체적 고통뿐만 아니라, 장기적인 투병생 활로 인한 심리적인 문제와 나아가서는 개인과 그 가족의 삶의 질에 영향을 미친다(Kim et al., 2008) 그 중에서도 특 히 당뇨병은 사회·경제적 수준의 향상과 더불어 그 발생 이 증가하는 것으로 알려진 대표적인 성인병 중의 하나이 다. 당뇨병은 인슐린 호르몬의 부족 혹은 결핍으로 인한 제 1 형 당뇨병과 인슐린 저항성에 의해 발병되는 제 2 형
당뇨병으로 분류되며, 이 중 제 2 형 당뇨병은 전체 당뇨병 환자의 $95 \%$ 이상을 차지하고 있다(Kim et al., 2011) 당뇨병 을 혈당 단계로 분류한다면, 정상 혈당수준, 당뇨병 혈당 수준과 이 둘 사이에 있는 당뇨병 전단계(pre-diabetes) 즉 공복혈당장애 수준이다. 이 수준은 제 2 형 당뇨병으로 발 병 가능성이 높은 고위험에 해당하기 때문에 당뇨병을 예방하기 위한 표적으로 최근에 많은 관심을 받는 단계이 다. 세계보건 기구조사에 의하면 당뇨병의 세계적인 추이 는 이미 제한된 어떤 특정 지역의 질환 한계를 넘어 세계 전역의 유행병 상태까지 이른 것으로 보고하였다. 특히 주 목해야 될 내용은 불행히도 당뇨병 환자가 아시아 지역 에서 가장 많이 증가될 것이라는 예측이다. 아시아 지역 의 당뇨병 환자수는 2000년 8,450만 명에서 2010년 57\%

Received: November 1, 2019 / Revised: November 18, 2019 / Accepted: November 25, 2019

* Professor.

†Corresponding author: Yun-Jung Kang. Department of Clinical Laboratory Science, Sang-ji University, Wonju 26339, Korea. Tel: +82-33-738-8081, Fax: +82-33-738-8082, e-mail: lvpig@naver.com

(C) The Korean Society for Biomedical Laboratory Sciences. All rights reserved.

(C) This is an Open Access article distributed under the terms of the Creative Commons Attribution Non-Commercial License (http://creativecommons.org/licenses/by-nc/3.0/) which permits unrestricted non-commercial use, distribution, and reproduction in any medium, provided the original work is properly cited. 
가 증가된 1 억 3,230 만 명으로 전 세계 당뇨병 인구의 약 $60 \%$ 를 차지하게 될 것 이라는 내용이다(Kim et al., 2005). 나아가 2025년까지 전 세계적으로 3억 3,300만 명에 달할 것으로 예상되는 제 2 형 당뇨병의 급속한 확산은 의료계와 정치계 양쪽에 불안을 야기한다(Van Dam et al., 2005). 인구 의 고령화에 따라 제 2 형 당뇨병의 유병자수는 더욱 증가 할 것으로 예상되는 가운데, 이에 대한 사회적-국가적으 로 우려를 하는 이유 중 하나는 수반되는 합병증 발병률 이 높다는 특성을 가지고 있기 때문이다(Choi and Jo, 2013). 당뇨병으로 인한 고혈당 증상은 혈관 손상을 가져와 당뇨 병성 미세혈관과 대혈관 합병증을 유발시켜 관상동맥 질 환, 뇌졸중, 안구질환, 당뇨병성 족부질환, 당뇨병성 신증 등을 유발할 수 있으며(Winocour, 2002), 심혈관질환의 위 험인자이다(Klein et al., 1984). 제2형 당뇨병은 유전적 요인 과 환경적 요인을 모두 갖는 질병이다(Bi et al., 2012). 질 병의 예방을 위해서는 모든 요인의 연구가 이루어져야 한 다. 하지만, 유전적 요인과 개인의 생활습관 및 개인적 행 동에 초점을 두는 연구는 많으나 사회적 맥락, 특히 사회 적 관계 및 사회적 환경을 고려한 연구들은 미흡한 실정 이다. 사회적 관계에는 사회적 지지가 있다. 사회적 지지 란 광범위한 의미에서 타인에 의해 제공되는 자원이라 할 수 있으며(Cohen and Wills, 1985), 사회적 지지에는 여러 유형이 있지만 두 개의 넓은 범주로서 긍정적 지지와 부 정적 지지가 있으며, 긍정적 지지에는 정서적 지지와 도 구적 지지로 분류하는 것이 유용하다. 정서적 지지는 애 정, 관심, 존경 등의 지지를 포함하며, 도구적 지지는 병간 호, 신체적 도움, 집안일 돕기, 물질적 지원 등과 같은 직 접적인 도움의 행동을 포함한다(Berkman and Syme, 1979). 사회적 지지가 신체 건강결과에 영향을 미치는 경로는 크 게 3 가지 즉 건강행동 경로, 심리적 경로, 생리적 경로로 요약된다. 첫째 건강행동 경로는 사회적 지지기능을 통하 여 흡연이나, 음주, 신체활동, 식이습관 같은 건강증진 혹 은 유해행동에 영향을 준다(Lewis and Rook, 1999). 둘째 심리적 경로는 사회적 지지는 자존감, 사회적 능력, 자기 효능감, 우울, 감정과 같은 인지적·정서적 상태에 영향을 준다(Cohen, 1988). 마지막으로 생리적 경로는 스트레스 반 응과 관련된 혈압상승, 심박출량 증가, 카테콜라민 상승 과 같은 과다한 자극과 면역반응의 억제와 같은 나쁜 영 향을 사회적 지지가 완충작용을 하고, 신경 내분비 호르 몬 옥시토신은 혈압을 낮추고 항 스트레스 작용을 함으로 써 건강결과에 직접적인 영향을 미칠 수 있다(Uchino et al., 1996).
이에 본 연구는 건강행동 경로와 심리적 경로, 생리적 경로를 반영한 구조방정식 분석으로 사회적 지지가 공복 혈당장애 및 제 2 형 당뇨병에 미치는 영향을 파악하고 요 인을 확인하여 개인의 질병이 사회관계와 상호작용에 기 인한 것임을 규명하고 질병의 원인을 개인에서 사회적 관 계로 포괄하여 탐구하고자 한다.

\section{대상 및 방법}

\section{변수의 정의}

결과변수: 당뇨병의 기준은 미국당뇨병학회(American Diabetes Association, ADA)의 기준으로 정의하였다(ADA, 1997). 이에 공복혈당 $100 \mathrm{mg} / \mathrm{dL}$ 미만을 정상으로, 당뇨병 전단 계(공복혈당장애)를 100 125 mg/dL로 분류하였으며, 당뇨 병 진단의 기준을 $126 \mathrm{mg} / \mathrm{dL}$ 이상 또는 의사의 진단 여부, 인슐린 혹은 경구혈당강하제를 복용하고 있는 경우로 정 의하였다.

주요 노출변수: 사회적 지지의 조사 척도는 $\mathrm{He}(\mathrm{He}, 2000)$ 의 척도를 사용하였다. 긍정적 지지 6 문항과 부정적 지 지 6 문항으로 나누어 구성하였다. 긍정적 지지의 6항목 Kuder-Richardson Formula 20 (KR-20)의 계수값은 0.80이었 고, 부정적 지지의 6항목 KR-20 계수값은 0.72 로 사회적 지지의 기능 점수 척도는 높은 신뢰도를 보였다. 긍정적 지지에 대한 조사는 '속사정을 털어놓을 수 있는 사람이 있다', '나에게 늘 관심을 갖고 걱정을 해주는 사람이 있다', '중요한 일이나 어려운 일이 있을 때 의논상대가 되어 주 는 사람이 있다'의 정서적 지지 3 문항과 '내가 아플 때 병 간호를 해주거나 집안일을 도와주는 사람이 있다', '필요한 것이 있으면 보태주거나 빌려주는 사람이 있다', '내가 요 청할 때마다 기꺼이 시간을 내주고 집안일을 도와주는 사 람이 있다'의 도구적 지지 3 문항으로 구성하여, 긍정적 지 지는 총 6 문항이다. 해당 지지의 제공 받은 여부를 아니요 (1), 예 (2)으로 응답하게 하여 점수를 부여하고 그 합을 계산하였다. 긍정적 지지 점수의 범위는 6 12점이며, 점 수가 높을수록 사회적 지지가 높음을 의미하며, 사회적 지지 도구 사용법(Berkman and Syme, 1979)을 참고하여 평 균값을 기준으로 상 - 하 집단으로 나누었다.

부정적 지지 문항은 많은 사람이 내가 하는 일에 간섭 하거나 반대한다', '현재 내가 갖고 있는 문제가 모두 내 탓이라고 비난하는 사람이 있다', '나를 무시하는 느낌을 주는 사람이 있다', '내가 원하지도 않는 도움을 줘서 마음 
을 불편하게 하는 사람이 있다', '내 주변에 나와 내 일에 무관심한 사람이 있다', '내가 도움을 요청하면 대부분 거 절을 하는 사람이 있다'의 6문항으로 구성하였으며, 해당 지지의 제공받음 여부를 아니오 (1), 그렇다 (2) 으로 응 답하게 하여 점수를 부여하고 그 합을 계산하였다. 부정 적 지지의 점수 범위는 6 12점이며, 점수가 높을수록 부 정적 지지가 높음을 의미하며, 사회적 지지 도구 사용법 (Berkman and Syme, 1979)을 참고하여 평균값을 기준으로 상 - 하 집단으로 나누었다.

공변량 변수: 본 연구에서 사용된 교란변수 및 공변량 변인은 일반적 특성과 건강습관 등이며, 본 연구 4장의 Table 3에서와 같다. 성별은 남성과, 여성으로 분류하였고, 연령은 30 대부터 40 대, 50 대, 60대, 그리고 70 대 이상으로 분류하였다. 교육수준은 초등학교 졸업, 중학교 졸업, 고 등학교 졸업, 전문대학교 이상으로 분류하였으며, 소득은 월 평균 가구소득을 의미하며, 200 만 원 미만과 200 만 원 이상 400 만 원 미만, 400 만 원 이상 600 만 원 미만, 600 만 원 이상으로 분류하였다. 배우자 유무는 법률적 관계보다 는 사실상의 관계를 중시하여, 기혼자라도 별거 중일 때 에는 배우자 없음으로 구분하였다. 주관적 건강상태는 양 호, 보통, 나쁨으로 구분하였고, 흡연과 음주는 전혀 없음, 이전에는 흡연이나 음주습관이 있었으나 현재는 없음, 그 리고 현재 그러한 습관이 있음의 세 범주로 구분하였다. 체질량지수는 저체중 $(\mathrm{BMI}<18.5)$, 정상 $(18.5 \leq \mathrm{BMI}<23)$, 과 체중 $(23 \leq \mathrm{BMI}<25)$, 비만(BMI $\geq 25)$ 으로 구분하였으며, 심 리사회적 웰빙지수(PWI)는 점수가 낮을수록 심리사회적 스트레스의 정도가 낮은 것으로 해석되며 저위험군(0 27) 과 고위험군(28 54)으로 분류하였다. 그리고 스트레스는 스트레스 상황의 노출빈도를 측정하는 것으로서 전혀 없 음, 가끔, 자주의 세 범주로 나뉜다. 마지막으로 규칙적 운동은 안 한다와 한다의 2 개 범주로 구분된다.

\section{자료 수집}

모든 연구 참여자에 대하여 성별, 연령, 교육, 수입, 결 혼상태 등의 사회인구 통계학적 특성과 흡연, 음주, 신체 활동, 주관적 건강상태, 심리사회적 웰빙지수 등의 건강 관련 생활습관, 과거질병력, 약물복용 여부 및 질병의 가 족력 등에 대해 숙련된 조사자들이 직접 인터뷰를 통하 여 설문지를 작성하였다.

신체계측: 신체계측(키, 체중, 허리둘레)은 얇은 옷을 입
은 상태에서 측정하였고, 체질량지수(Body Mass Index)는 체중을 신장의 제곱으로 나누어 계산하였으며, 체질량지 수에 따라 $18.5\left(\mathrm{~m} / \mathrm{kg}^{2}\right)$ 미만을 저체중, $18.5 \sim 23\left(\mathrm{~m} / \mathrm{kg}^{2}\right)$ 미 만 군을 정상, 23 25 (m/kg $)$ 미만 군을 과체중, $25\left(\mathrm{~m} / \mathrm{kg}^{2}\right)$ 이상 군을 비만으로 분류하였다(Wen et al., 2009).

생화학적 검사: 공복혈당은 FBS (fasting blood sugar)로 측정하였으며, $\mathrm{FBS}$ 분석방법은 $\mathrm{SST} 5 \mathrm{~mL}$ 튜브(Sekisui Chemical Co, Osaka, Japan)로 채혈한 혈액을 30 분 이내 혈 청분리 후 Modular analytics P800 (Hitachi /Japan) 장비를 이용하여 UV test (Hexokinase Assay)으로 측정하였다.

\section{연구 대상자}

본 연구는 당뇨병, 고혈압, 골다공증, 호흡기질환, 대사 증후군 등의 만성질환의 예방을 위해서 발병과 관련한 위 험요인을 알고 이를 사전에 관리하기 위하여 전국 8개 대학병원에서 설문조사와 생체시료를 동시에 수집하는 "건강검진 수진자 코호트(Korean Health Examine Cohort, $\mathrm{KOEX}) "$ 연구에 참여 동의 후 등록한 참여자를 대상으로 하고 있다. 2004 2010년(1 7차) 동안 2 7차 KOEX 연구 에 등록한 30세 이상의 성인 53,767명 중 주요 변수인 제 2형 당뇨병과 관련이 있는 만성질환(뇌졸중, 협심증/심근 경색, 고혈압, 고지혈증, 지방간, 만성간염/간경변, 암)에 대한 질병력이 있는 표본 18,618 명을 제외하였다. 이들 중 연구목적의 주요변수인 사회적 지지, 당뇨병에 대한 자료 가 충실한 대상자 총 34,316 명을 대상으로 한다. 이 연구 는 천안 단국대학교 윤리기관 검토위원회 의해 승인되었 다(IRB No. 2014-04-006).

\section{자료분석 방법}

최종데이터는 SPSS 18.0 Windows ver.과 AMOS 18.0 프 로그램을 이용해 분석하였으며, 일반적 특성을 알아보기 위해 빈도분석 및 기술통계를 실시하였고, 일반적 특성과 공복혈당과의 관계를 알아보기 위해 카이스퀘어검정을 통 해 $P$ 값을 도출하였다. 질병에 대한 사회적 지지의 역할 을 알아보기 위해, 선행연구를 통해 구조모형을 추정하고 이를 검증하였다.

\section{결 과}

\section{대상자의 일반적 특성}

표본 특성은 Table 1 과 같다. 전체표본의 수는 34,316 이 
Table 1. General characteristics

\begin{tabular}{|c|c|c|c|}
\hline \multicolumn{2}{|c|}{ Characteristics \& variables } & \multirow{2}{*}{$\begin{array}{c}\begin{array}{c}\text { All } \\
(\mathrm{n}=34,316)\end{array} \\
11,367\end{array}$} & \multirow{2}{*}{$\begin{array}{c}\% \\
33.1\end{array}$} \\
\hline \multirow{2}{*}{ Sex } & Male & & \\
\hline & Female & 22,949 & 66.9 \\
\hline \multirow{6}{*}{ Age (years) } & Mean \pm SD & \multicolumn{2}{|c|}{$52.5 \pm 8.1$} \\
\hline & $30 \sim 39$ & 123 & 0.4 \\
\hline & $40 \sim 49$ & 13,421 & 39.1 \\
\hline & $50 \sim 59$ & 13,396 & 39.0 \\
\hline & $60 \sim 69$ & 6,787 & 19.8 \\
\hline & $>70$ & 589 & 1.7 \\
\hline \multirow{5}{*}{$\begin{array}{l}\text { Educational } \\
\text { level (years) }\end{array}$} & Elementary & 5,924 & 17.5 \\
\hline & Middle & 5,858 & 17.3 \\
\hline & High & 12,607 & 37.2 \\
\hline & College & 9,491 & 28.0 \\
\hline & Unknown & 436 & \\
\hline \multirow{5}{*}{$\begin{array}{l}\text { Household } \\
\text { income } \\
\text { (10 thousand } \\
\text { KW/month) }\end{array}$} & $<200$ & 9,477 & 31.9 \\
\hline & $200 \sim 400$ & 12,426 & 41.8 \\
\hline & $400 \sim 600$ & 5,309 & 17.9 \\
\hline & $\geq 600$ & 2,517 & 8.4 \\
\hline & Unknown & 4,587 & \\
\hline \multirow{3}{*}{$\begin{array}{l}\text { Marita } \\
\text { status }\end{array}$} & Single & 3,443 & 10.1 \\
\hline & Married & 30,746 & 89.9 \\
\hline & Unknown & 127 & \\
\hline \multirow{4}{*}{$\begin{array}{l}\text { Self-rated } \\
\text { health }\end{array}$} & Good & 13,542 & 39.7 \\
\hline & Medium & 15,049 & 44.1 \\
\hline & $\mathrm{Bad}$ & 5,541 & 16.2 \\
\hline & Unknown & 184 & \\
\hline \multirow{4}{*}{ Smoking } & Never & 25,302 & 74.0 \\
\hline & Former & 4,619 & 13.5 \\
\hline & Current & 4,279 & 12.5 \\
\hline & Unknown & 116 & \\
\hline \multirow{4}{*}{ Drinking } & Never & 18,383 & 53.7 \\
\hline & Former & 1,056 & 3.1 \\
\hline & Current & 14,773 & 43.2 \\
\hline & Unknown & 104 & \\
\hline \multirow{5}{*}{$\mathrm{BMI}^{\mathrm{a}}$} & Under weight & 576 & 1.7 \\
\hline & Normal & 12,350 & 36.0 \\
\hline & Over weight & 9,845 & 28.7 \\
\hline & Obesity & 11,495 & 33.6 \\
\hline & Unknown & 50 & \\
\hline \multirow{3}{*}{$\mathrm{PWI}^{\mathrm{b}}$} & Low & 30,135 & 90.3 \\
\hline & High & 3,219 & 9.7 \\
\hline & Unknown & 962 & \\
\hline Stress & Never & 18,997 & 56.0 \\
\hline
\end{tabular}

Table 1. General characteristics (Continued)

\begin{tabular}{llcr}
\hline \hline \multicolumn{1}{c}{ Characteristics \& variables } & $\begin{array}{c}\text { All } \\
(\mathrm{n}=34,316)\end{array}$ & $\%$ \\
\hline \multirow{3}{*}{ Stress } & Sometimes & 12,109 & 35.7 \\
& Often & 2,829 & 8.3 \\
& Unknown & 381 & \\
\hline \multirow{2}{*}{ Physical } & No & 16,118 & 47.0 \\
exercise & Yes & 18,160 & 53.0 \\
& Unknown & 38 & \\
\hline \multirow{2}{*}{$\begin{array}{l}\text { Positive } \\
\text { support }\end{array}$} & Mean \pm SD & $11.3 \pm 1.3$ \\
& High & 23,931 & 69.7 \\
\hline \multirow{2}{*}{$\begin{array}{l}\text { Negative } \\
\text { support }\end{array}$} & Low & 10,385 & 30.3 \\
& Low \pm SD & \multicolumn{2}{c}{$6.6 \pm 1.2$} \\
\hline
\end{tabular}

a: body mass index; Underweight (BMI <18.5), Normal $(18.5 \leq$ BMI $<23)$, Overweight $(23 \leq$ BMI $<25)$, Obesity $($ BMI $\geq 25)$

b: psychosocial well-being index; Low risk group (PWI $\leq 27)$, High risk group (PWI $\geq 28$ )

며, 이중 유효표본의 수는 각 특성별로 조금씩 차이가 있 다. 일반적 특성을 살펴보면, 먼저 성별에 따라서는 남성 (33.1\%)보다 여성(66.9\%)의 비율이 높았고, 연령은 $52.5 \pm$ 8.1 이였으며, 교육수준은 고졸자(37.2\%)가 가장 많은 것으 로 나타났다. 소득수준은 200 400만 원대 그룹(41.8\%)이 가장 많았고, 배우자 유무는 배우자가 있는 그룹(89.9\%) 이 압도적으로 많았다. 주관적 건강상태는 보통(44.1\%) 이 가장 많았고, 양호(39.7\%)가 그 다음이었으며, 건강하 지 않다고 응답한 대상자는 $16.2 \%$ 에 불과했다. 현재 흡연 율은 $12.5 \%$ 였으며, 비만 유병률은 $33.5 \%$ 이었다. 심리사회 적 웰빙지수는 평균 이하로 낮은 집단이 무려 $90.3 \%$ 에 달 했으며, 스트레스는 없다고 응답한 집단이 $56.0 \%$, 가끔 스트레스를 겪는다고 응답한 집단이 $35.7 \%$ 에 해당하였다. 그리고 규칙적 운동을 한다고 응답한 집단이 $53.0 \%$ 로 나 타났다. 긍정적 지지는 표본 전체의 평균보다 높은 집단 $(69.7 \%)$ 이 더 많았고, 반대로 부정적지지는 표본 전체의 평균보다 낮은 집단(68.0\%)이 더 많은 것으로 나타나 전 반적으로 응답자의 사회적 지지는 높은 것으로 파악된다 (Table 1).

\section{대상자의 일반적 특성에 따른 공복혈당장애 및 제2형 당뇨병}

일반적 특성과 공복혈당과의 관계를 분석한 결과는 
Table 2. Fast blood sugar according to general characteristics

\begin{tabular}{|c|c|c|c|c|c|}
\hline \multirow{2}{*}{\multicolumn{2}{|c|}{ Characteristics all $(\mathrm{n}=34,316)$}} & \multicolumn{3}{|c|}{ FBS, n (\%) } & \multirow{3}{*}{$P$-value } \\
\hline & & \multirow{2}{*}{$\begin{array}{c}\text { Normal } \\
25,079\end{array}$} & \multirow{2}{*}{$\begin{array}{c}\text { IFG } \\
5,647\end{array}$} & \multirow{2}{*}{$\begin{array}{c}\mathrm{DM} \\
3,590\end{array}$} & \\
\hline & & & & & \\
\hline \multirow{2}{*}{ Gender } & Male & $7,261(63.9)$ & $2,654(23.3)$ & $1,452(12.8)$ & \multirow{2}{*}{$<0.001$} \\
\hline & Female & 17,818 (77.6) & 2,993 (13.0) & $2,138(9.3)$ & \\
\hline \multirow{5}{*}{ Age (years) } & $30 \sim 39$ & $109(88.6)$ & $6(4.9)$ & $8(6.5)$ & \multirow{5}{*}{$<0.001$} \\
\hline & $40 \sim 49$ & $10,559(78.7)$ & $1,702(12.7)$ & $1,160(8.6)$ & \\
\hline & $50 \sim 59$ & 8,585 (71.6) & 2,367 (17.7) & $1,444(10.8)$ & \\
\hline & $60 \sim 69$ & $4,465(65.8)$ & $1,432(21.1)$ & 890 (13.1) & \\
\hline & $>70$ & $361(61.3)$ & $140(23.8)$ & $88(14.9)$ & \\
\hline \multirow{5}{*}{$\begin{array}{l}\text { Educational level } \\
\text { (years) }\end{array}$} & Elementary & $4,096(69.1)$ & 1,098 (18.5) & $730(12.3)$ & \multirow{5}{*}{$<0.001$} \\
\hline & Middle & 4,169 (71.2) & 1,033 (17.6) & $656(11.2)$ & \\
\hline & High & $8,429(74.8)$ & 1,967 (15.6) & $1,211(9.6)$ & \\
\hline & College & $7,072(74.5)$ & 1,478 (15.6) & 941 (9.9) & \\
\hline & Unknown & $436(1.3)$ & & & \\
\hline \multirow{5}{*}{$\begin{array}{l}\text { Household income } \\
\text { (10 thousand } \\
\text { KW/month) }\end{array}$} & $<200$ & 6,675 (70.4) & $1,736(18.3)$ & 1,066 (11.2) & \multirow{5}{*}{$<0.001$} \\
\hline & $200 \sim 400$ & $9,213(74.1)$ & $1,953(15.7)$ & $1,260(10.1)$ & \\
\hline & $400 \sim 600$ & 3,987 (75.1) & 798 (15.0) & $524(9.9)$ & \\
\hline & $\geq 600$ & $1,936(76.9)$ & $356(14.1)$ & $225(8.9)$ & \\
\hline & Unknown & 4,587 (13.4) & & & \\
\hline \multirow{3}{*}{ Marital status } & Single & $2,522(73.3)$ & $556(16.1)$ & $365(10.6)$ & \multirow{3}{*}{0.840} \\
\hline & Married & $22,455(73.0)$ & $5,079(16.5)$ & $3,212(10.4)$ & \\
\hline & Unknown & $127(0.4)$ & & & \\
\hline \multirow{4}{*}{ Self-rated health } & Good & $10,013(73.9)$ & $2,225(16.4)$ & $1,304(9.6)$ & \multirow{4}{*}{$<0.001$} \\
\hline & Medium & $11,051(73.4)$ & 2,437 (16.2) & $1,561(10.4)$ & \\
\hline & $\mathrm{Bad}$ & $3,889(70.2)$ & $948(17.1)$ & 704 (12.7) & \\
\hline & Unknown & $184(0.5)$ & & & \\
\hline \multirow{4}{*}{ Smoking } & Never & $19,293(76.3)$ & $3,575(14.1)$ & $2,434(9.6)$ & \multirow{4}{*}{$<0.001$} \\
\hline & Former & $2,868(62.1)$ & $1,151(24.9)$ & $600(13.0)$ & \\
\hline & Current & 2,819 (65.9) & $910(21.3)$ & $550(12.9)$ & \\
\hline & Unknown & $116(0.3)$ & & & \\
\hline \multirow{4}{*}{ Drinking } & Never & $13,893(75.6)$ & $2,619(14.2)$ & $1,871(10.2)$ & \multirow{4}{*}{$<0.001$} \\
\hline & Former & $711(67.3)$ & 217 (20.5) & $128(12.1)$ & \\
\hline & Current & $10,390(70.3)$ & 2,799 (18.9) & 1,584 (10.7) & \\
\hline & Unknown & $104(0.3)$ & & & \\
\hline \multirow{5}{*}{$\mathrm{BMI}^{\mathrm{a}}$} & Under weight & $484(84.0)$ & $52(9.0)$ & $40(6.9)$ & \multirow{5}{*}{$<0.001$} \\
\hline & Normal & 9,808 (79.4) & $1,476(12.0)$ & $1,066(8.6)$ & \\
\hline & Over weight & 7,145 (72.6) & $1,666(16.9)$ & $1,034(10.5)$ & \\
\hline & Obesity & 7,608 (66.2) & 2,444 (21.3) & 1,443 (12.6) & \\
\hline & Unknown & $50(0.1)$ & & & \\
\hline \multirow{3}{*}{$\mathrm{PWI}^{\mathrm{b}}$} & Low & $22,009(73.0)$ & 4,969 (16.5) & 3,157 (10.5) & \\
\hline & High & $2,373(73.7)$ & $511(15.9)$ & 335 (10.4) & 0.648 \\
\hline & Unknown & $962(2.8)$ & & & \\
\hline
\end{tabular}


Table 2. Fast blood sugar according to general characteristics (Continued)

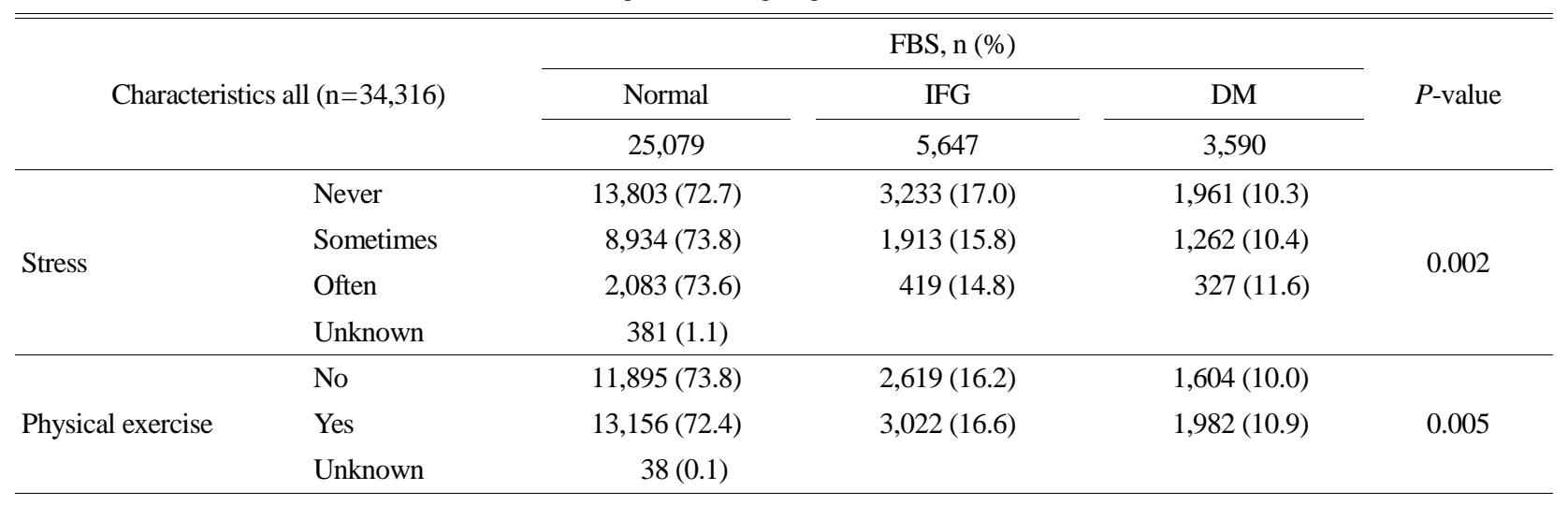

a: body mass index; Underweight (BMI <18.5), Normal (18.5 $\leq$ BMI $<23)$, Overweight $(23 \leq \mathrm{BMI}<25)$, Obesity (BMI $\geq 25)$

b: psychosocial well-being index; Low risk group (PWI <27), High risk group (PWI $\geq 27$ )

Table 2과 같다. 배우자 유무와 심리사회적 웰빙지수(PWI: Psychosocial Well-being Index)를 제외하고, 성별, 연령, 교육 수준, 가구소득, 주관적 건강상태, 흡연습관, 음주습관, 체 질량지수(BMI; Body Mass Index), 스트레스, 그리고 규칙적 운동에 따라 유의미한 차이가 있는 것으로 나타났다. 여 성보다 남성에서 공복혈당장애와 당뇨병 유병률이 더 높 은 비율로 발견되었으며, 연령이 증가할수록 공복혈당장 애와 당뇨병 유병률이 증가하는 것으로 나타났다. 또한 교육수준과 소득이 낮을수록 공복혈당장애와 당뇨병 유병 률이 유의미하게 더 높은 비율로 나타났다. 주관적 건강 상태는 건강하지 않다고 인식하는 집단에서 공복혈당장 애와 당뇨병 유병률이 더 높아지는 것을 알 수 있다. 음주 습관 및 흡연습관의 경우, 무경험자에 비해 이전 또는 현 재에 음주나 흡연습관을 가진 집단에서 공복혈당장애와 당뇨병 유병률이 높은 것으로 나타났다. 또한 체질량지수 가 증가할수록 공복혈당장애 또는 당뇨병 유병률이 더 증 가하였으며, 심리사회적 웰빙지수가 낮은 집단에서 공복 혈당장애와 당뇨병 유병률 더 높게 발견되었다(Table 2).

\section{구조모형의 검증}

모형의 추정 및 가설: 선행연구의 이론고찰을 토대로 사 회적 지지의 건강 또는 질병에 대한 설명모델로서 심리적 경로와 행동적 경로를 반영하여 Fig. 1과 같은 구조모형을 설정하였다. 구조모형은 회귀분석과 달리 측정변수를 통 해 가설적 개념인 잠재변인을 생성하고, 공변량 분해를 통해 잠재변수들 간의 복잡한 인과관계를 체계적으로 쉽 게 이해하는 데 큰 도움을 준다. 또한, 모형에 내재된 측 정오차를 알 수 있고, 나아가 측정모형과 이론 모형 간의

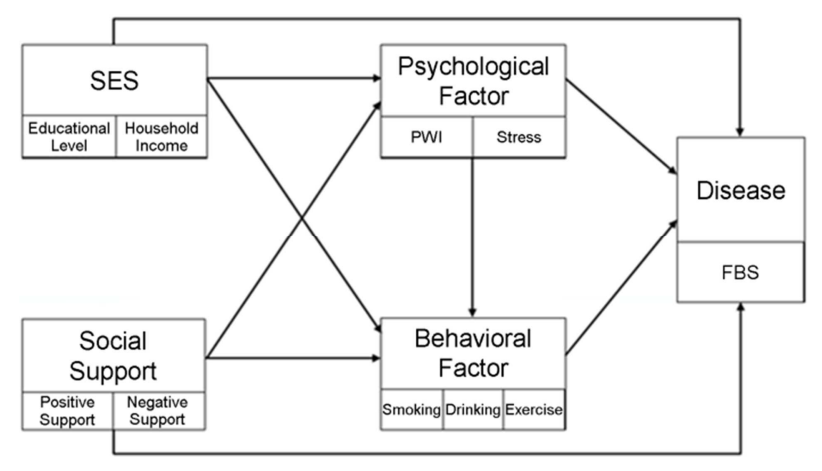

Fig. 1. Hypothetical model of social support to disease.

관계를 전체적인 관점에서 검증할 수 있다는 점에서 큰 의의가 있다. 측정변인들은 앞의 분석에서 사용한 변수와 동일하며, 해당 변수들을 사용해 사회경제적 지위(SES), 사회적 지지, 심리적 요인, 행동적 요인, 질병의 잠재변인 들을 도출하고, 잠재변인들 간의 관계를 알아보고자 하였 다. 이때 관측변수로 사용한 변인들은 잠재변인의 개념 과 일치하도록 부정적 지지, 심리사회적 웰빙지수, 스트 레스, 흡연습관, 음주습관을 역방향으로 계측하였으며 사 회적 지지는 긍정적 지지는 정방향으로 계측한 값과 부 정적 지지는 역방향으로 계측한 값을 합산하여 계측하였 다(Fig. 1).

\section{모형의 적합성 검증:}

\section{(1) 잠재변인의 개념신뢰도 및 판별타당도}

추정모형의 잠재변인은 관측변인의 수가 적어 확인요인 
분석을 실시하기에 적합하지 않다. 따라서 개념신뢰도와 분산추출지수, 그리고 판별타당도 검증을 통해 가설적 개 념이 올바르게 설정되었는지 확인해보았다. 개념신뢰도 (CR: Construct Reliability)는 잠재변인에 대한 측정변인들 의 내적 일관성을 측정하는 데 이용된다. 개념신뢰도의 계산방법은 다음과 같다.

$$
C R=\frac{(\Sigma \text { 표준적재치 })^{2}}{\left[(\Sigma \text { 표준적재치 })^{2}+\Sigma \text { 측정오차 }\right]}
$$

또한 평균분산추출(AVE: Average Variance Extracted)을 검증하여 신뢰성 평가를 하였다. AVE는 측정오차에 기인 한 변량과 비교했을 때 설명되는 변량의 크기를 나타내 며, 다음과 같이 계산된다.

$$
A V E=\frac{\Sigma(\text { 표준적재치 })^{2}}{\left[\Sigma(\text { 표준적재치 })^{2}+\Sigma \text { 측정오차 }\right]}
$$

이러한 공식에 따라 개념신뢰도와 평균분산추출지수를 Table 3에 나타내었다. 분석결과, 각 요인의 표준적재치가 0.5 이상이므로 개념타당성은 확보되었다. 또한 이에 대한 개념신뢰도는 0.68 0.79로 내적 일관성이 있다고 할 수 있다. 그리고 평균분산추출지수는 모두 $0.53 \sim 0.64$ 로 나타 나 수렴타당성도 확인되었다(Table 3).

다음으로 판별타당성을 확인하였다. 개념신뢰도가 잠재 변인과 측정변인이 서로 얼마나 일치하는가를 보는 것이 라면, 판별타당도는 잠재변인들이 서로 얼마나 상이한가 를 보는 것이다. 판별타당성을 가장 엄격하게 판단하는 기준은 평균분산추출지수가 상관계수의 제곱 $\left(\phi^{2}\right)$ 값을 상
회하는지 여부(Fornell \& Larcker, 1981)로 판단하는 것이다. 먼저 잠재변인들 간의 상관관계를 분석한 결과는 Table 4 와 같다. 상관관계분석은 하나의 속성이나 개념의 상태 에 대한 측정이 다른 속성이나 개념의 상태변화를 예측하 는지를 판단하는 데 의의가 있다. 본 연구에서 상정한 구 조모형의 관계에서 사회적 지지와 질병, 심리적 요인과 질병 간에는 상호 간을 유의미하게 예측하지 못하는 것 으로 나타났으나, 그 외의 모든 관계에서는 잠재변인들 간 유의미한 상관관계가 있는 것으로 나타났다(Table 4).

이러한 상관계수를 이용해 판별타당성을 검증하였으며 분석결과는 다음 Table 5 와 같다. 측정변인이 하나로만 구 성된 질병을 제외하고, 모든 차원에서 잠재변인들 간의 $\mathrm{r}$-square $\left(\phi^{2}\right)$ 값은 0.5 미만으로 각 잠재변인의 AVE 값보

\begin{tabular}{|c|c|c|c|}
\hline & Variables & $\begin{array}{l}\text { Correlation } \\
\text { coefficient }\end{array}$ & $P$ \\
\hline SES & $\leftrightarrow$ Social support & 0.136 & $<0.001$ \\
\hline SES & $\leftrightarrow$ Behavioral factors & -0.214 & $<0.001$ \\
\hline $\begin{array}{r}\text { Psychological } \\
\text { factors }\end{array}$ & $\leftrightarrow$ Social support & 0.597 & $<0.001$ \\
\hline $\begin{array}{r}\text { Psychological } \\
\text { factors }\end{array}$ & $\leftrightarrow$ Behavioral factors & -0.079 & $<0.001$ \\
\hline $\begin{array}{r}\text { Psychological } \\
\text { factors }\end{array}$ & $\leftrightarrow \mathrm{SES}$ & 0.213 & $<0.001$ \\
\hline Social support & $\leftrightarrow$ Behavioral factors & 0.018 & 0.048 \\
\hline Disease & $\leftrightarrow$ Behavioral factors & -0.106 & $<0.001$ \\
\hline Disease & $\leftrightarrow \begin{array}{l}\text { Psychological } \\
\text { factors }\end{array}$ & 0.006 & 0.473 \\
\hline Disease & $\leftrightarrow \mathrm{SES}$ & -0.054 & $<0.001$ \\
\hline Disease & $\leftrightarrow$ Social support & 0.004 & 0.659 \\
\hline
\end{tabular}

Table 4. Correlations among latent variables

\begin{tabular}{|c|c|c|c|c|c|}
\hline \multicolumn{2}{|c|}{ Variables } & SRE & ME & $\mathrm{CR}$ & AVE \\
\hline \multirow{2}{*}{ SES } & Educational level & 0.849 & 0.305 & \multirow{2}{*}{0.68} & \multirow{2}{*}{0.53} \\
\hline & Household income & 0.545 & 0.590 & & \\
\hline \multirow{2}{*}{ Social support } & Positive support & 0.559 & 0.167 & \multirow{2}{*}{0.78} & \multirow{2}{*}{0.64} \\
\hline & Negative support & 0.542 & 0.175 & & \\
\hline \multirow{2}{*}{ Psychological factors } & PWI & 0.578 & 0.303 & \multirow{2}{*}{0.69} & \multirow{2}{*}{0.53} \\
\hline & Stress & 0.568 & 0.278 & & \\
\hline \multirow{3}{*}{ Behavioral factors } & Smoking & 0.614 & 0.249 & \multirow{3}{*}{0.79} & \multirow{3}{*}{0.56} \\
\hline & Drinking & 0.629 & 0.258 & & \\
\hline & Physical exercise & 0.536 & 0.325 & & \\
\hline
\end{tabular}

Table 3. Construct reliability and average variance extracted of variables 
다 작기 때문에 판별타당성은 확보되었다고 할 수 있다 (Table 5).

\section{(2) 모형적합도}

본 연구에서 상정한 가설 검증에 앞서 구조모형의 적합 성(model fit)을 검증하였으며, 그 결과는 Table 6와 같다. 다만 관측변수에 결측값이 포함된 데이터 셋을 사용해 분 석하였기 때문에, 적합지수 중 GFI 및 $\mathrm{AGFI}$ 는 계산하지 못하였다. 먼저 절대적합지수 중 카이자승 $\left(\chi^{2}\right)$ 통계량이 74.50 으로 높게 나타나 정규분포를 이루는 귀무가설을 채 택하지 못하였다. 그러나 RMSEA $=0.04$ 로 나타나 적합성 요건을 충족하였다. 증분적합지수 중 $\mathrm{NFI}=0.95, \mathrm{CFI}=0.94$ 으로 적합한 것으로 나타났고, 간명적합지수인 $\mathrm{TLI}=0.90$

Table 5. Discriminant validity among latent variables

\begin{tabular}{lcccc}
\hline \hline & $\mathrm{a}$ & $\mathrm{b}$ & $\mathrm{c}$ & $\mathrm{d}$ \\
\hline a: SES & $\begin{array}{c}\mathbf{A V E}= \\
\mathbf{0 . 5 3}\end{array}$ & & & \\
$\begin{array}{l}\text { b: Social } \\
\text { support }\end{array}$ & 0.02 & $\begin{array}{c}\mathbf{A V E}= \\
\mathbf{0 . 6 4}\end{array}$ & & \\
$\begin{array}{l}\text { c: Psychological } \\
\text { factors }\end{array}$ & 0.05 & 0.36 & $\begin{array}{c}\mathbf{A V E}= \\
\mathbf{0 . 5 3}\end{array}$ & \\
$\begin{array}{l}\text { d: Behavioral } \\
\text { factors }\end{array}$ & 0.05 & 0.00 & 0.01 & $\begin{array}{c}\mathbf{A V E}= \\
\mathbf{0 . 5 6}\end{array}$ \\
\hline
\end{tabular}

으로 나타나 최종적으로 모형은 적합한 것으로 판정하 였다.

모형의 가설 검증: 모형에 대한 분석결과는 Table 7과 같 으며, 상대적인 영향력의 크기를 알아보기 위해 표준화 해를 통해 제시하였다. 모형에서 상정한 총 9 개의 경로에 대하여 $P<0.05$ 수준에서 통계적으로 유의미한 경로는 7 개로 나타났다. 구체적으로 살펴보면 다음과 같다. 먼저, 심리적 요인의 변량에 대한 외생변수들의 설명력은 $49.6 \%$

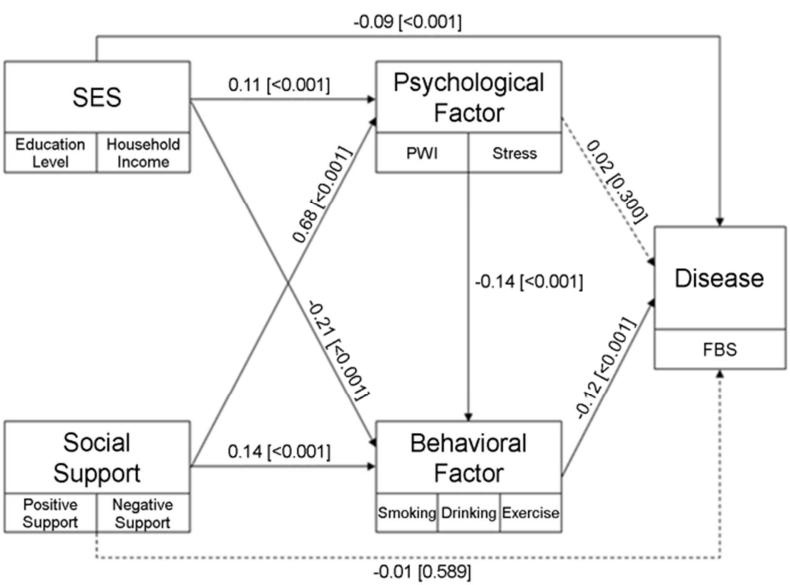

Fig. 2. Path diagram for model.

Table 6. Model fit for the hypothetical model

\begin{tabular}{lcccccccc}
\hline \hline \multirow{2}{*}{ Indices } & \multicolumn{2}{c}{ Absolute fit measures } & & \multicolumn{2}{c}{ Incremental fit measures } & & \multicolumn{2}{c}{ Parsimonious fit measures } \\
\cline { 2 - 3 } & $\chi^{2}(P)$ & RMSEA & & NFI & & CFI & & TLI \\
\hline Values & $74.50(<0.05)$ & 0.04 & & 0.95 & 0.94 & & 0.90 \\
\hline
\end{tabular}

Table 7. Standardized regression weights

\begin{tabular}{llccc}
\hline \hline Endogenous variables & Exogenous variables & Estimate & $P$-value & SMC \\
\hline \multirow{2}{*}{ Psychological factors } & SES & 0.112 & $<0.001$ & 0.496 \\
& Social support & 0.679 & $<0.001$ & \\
\hline \multirow{3}{*}{ Behavioral factors } & SES & -0.205 & $<0.001$ & 0.158 \\
& Social support & 0.140 & $<0.001$ & \\
& Psychological factors & -0.139 & $<0.001$ & 0.119 \\
Disease & SES & -0.088 & $<0.001$ & 0.589 \\
& Social support & -0.011 & 0.300 & $<0.001$ \\
\end{tabular}


로 비교적 높게 나타났다. 즉, 사회적 지지 $(\gamma=0.68)$ 와 사 회경제적 지위 $(\gamma=0.11)$ 는 심리적 요인을 유의미하게 증가 시키는 것으로 나타났다. 행동적 요인에 대한 외생변수들 의 설명력은 $15.8 \%$ 로 나타났으며, 사회적 지지 $(\gamma=0.14)$ 가 행동적 요인을 유의미하게 증가시키며, 심리적 요인 $(\gamma=$ $-0.14)$ 과 사회경제적 지위 $(\gamma=-0.21)$ 는 행동적 요인을 유의 미하게 감소시키는 것으로 나타났다. 질병에 대한 외생 변수들의 설명력은 $11.9 \%$ 로 나타났으며, 행동적 요인 $(\gamma=$ $-0.12)$ 과 사회경제적 지위 $(\gamma=-0.09)$ 가 질병을 유의미하게 감소시키는 것으로 나타났다(Table 7). 분석결과에 대한 모형의 경로도해를 Fig. 2에 나타내었다.

\section{고 찰}

사회적 지지와 사회경제적 지위는 심리적 요인을 유의 미하게 증가시키는 것으로 나타났다. 또한 사회적 지지가 행동적 요인을 유의미하게 증가시키며, 심리적 요인과 사 회경제적 지위는 행동적 요인을 유의미하게 감소시키는 것으로 나타났다. 행동적 요인과 사회경제적 지위가 질병 을 유의미하게 감소시키는 것으로 나타났다. 즉, 사회적 지지가 행동적 요인을 증가시켰으며, 행동적 요인은 질병 을 감소시킨 결과이다. 사회적 지지로 인해 흡연과 음주 는 감소되고 운동은 증가시켜 긍정적인 행동적 요인으로 작용되어 공복혈당과 제 2 형 당뇨병을 유의미하게 감소시 켰다. 사회적 지지가 건강결과에 영향을 주는 세 가지의 경로 중 건강행동 경로가 성립된 결과이다. 건강행동 경 로는 사회적 지지기능을 통하여 흡연이나, 음주, 신체활 동, 식이습관 같은 건강증진 혹은 유해행동에 영향을 준 다(Lewis and Rook, 1999). 사회적 지지가 건강행동들에 영 향을 미치는 것은 여러 가지 방법들이 있다. 첫째, 사회 적 지지는 더 나은 건강행동들을 촉진시킬 수도 있다. 왜 냐하면 그것은 개인이 경험할 수 있는 스트레스의 양을 감소시킬 수 있기 때문이다. 둘째, 사회적 지지는 개인에 게 직접적으로 더 건강한 실천행동들에 참여하도록 동기 유발을 할 수도 있다. 예를 들어, 가까운 가족 구성원들은 개인이 운동을 하거나 금연하도록 압력을 가할 수도 있 다는 것이다. 그리고 적절한 사회적 지지를 가지는 것은 한 사람이 사랑을 받는다는 사실을 알려주고, 이것은 스 스로를 돌보는 동기를 증가하게 만들어 더 나은 건강행 동들을 이끌어 나갈 수 있다. 심리적 경로는 본 연구결과 에서는 유의미하지 않았다. 심리적 경로는 자존감, 사회 적 능력, 자기효능감, 우울 등의 변수가 중요한데, 본 연
구는 변수 측정의 한계로 심리적 경로의 변수로 심리사 회적 웰빙지수만 활용되었기 때문이라고 생각된다. 추후 연구에서는 모든 변수가 고려된 연구가 필요할 것이다. 마지막으로 건강결과에 직접적인 영향을 미칠 수 있는 (Uchino et al., 1996) 생리적 경로는 유의미하지 않았다. 사 회적 지지는 건강에 직접 영향을 주는 것보다는 사회적 지지로 인하여 건강행동들을 실천할 때 건강에 영향을 주 는 것이라고 생각된다. 본 연구는 사회적 지지가 건강행 동에 영향을 주어 공복혈당을 낮추는 것으로 나타났다. 따라서, 제 2 형 당뇨병의 예방을 위해서는 개인의 위험요 인의 관리 뿐만 아니라, 사회적 지지 등과 같은 사회적 관계의 관심 갖고 건강행동을 실천하는 것이 질병을 줄 일 수 있는 방안이라 하겠다. 본 논문은 제한점이 있다. 첫째, 단면연구이므로 사회적 지지와 공복혈당장애와의 관련성에 대해 인과관계를 논하지 못하며, 당뇨병 환자일 경우, 오히려 주변의 관심으로 사회적 지지가 높을 수 있 는 역 인과관계가 존재할 수 있다. 둘째, 연구의 조사대 상이 건강검진 수검자라는 특정 인구집단을 대상으로 이 루어졌기 때문에 연구결과를 일반화 시키는 데는 제한점 이 있다고 생각한다. 셋째, 당뇨병을 진단하는데 있어서 공복혈당으로만 진단되고, 당부하검사를 이용하지 못한 제한점이 있다. 넷째, 사회적 지지는 누가 지지를 제공하 느냐에 따라 그 효과가 다양하게 나타나는데 본 연구에 서는 지지 원천의 평가는 고려되지 않았다. 따라서 이후 의 연구에서는 제한점을 보완한 연구가 제시되어야 할 것이다. 이러한 제한점이 있음에도 본 연구는 전국 8 개 대학병원에서 설문조사와 생체시료를 동시에 수집한 자료 를 이용하여 사회적 지지와 공복혈당장애의 관계를 성별 의 차이를 고려하여 살펴보았으며, 사회적 관계망의 긍정 적 기능과 부정적 기능을, 긍정적 지지와 부정적 지지로 측정하여 함께 고려한 연구이며, 개인의 건강문제를 생물 학적 접근에서 벗어나 사회적 맥락에서 바라보고자 질병 의 원인을 개인에서 사회적 관계로 포괄하여 탐구하였다 는데 의의가 있다.

\section{ACKNOWLEDGEMENT}

None.

\section{CONFLICT OF INTEREST}

No potential conflict of interest relevant to this article was reported. 


\section{REFERENCES}

ADA International Expert Committee: Report of the Expert Committee on the diagnosis and classification of diabetes mellitus. Diabetes Care. 1997. 20: 1183-1197.

Berkman LF, Syme SL. Social networks, host resistance, and mortality: a nine-year follow-up study of Alameda County residents. Am J Epidemiol. 1979. 109: 186-204.

Bi Y, Wang T, Xu M, Xu Y, Li M, Lu J, et al. Advanced research on risk factors of type 2 diabetes. Diabetes Metab Res Rev. 2012. 28: 32-39.

Choi MJ, Jo HJ. Effects of Green Tea Powder on Bone Markers and Bone Mineral Density in STZ-Induced Diabetic Rats. J East Asian Soc Dietary Life. 2013. 23: 713-722.

Cohen S, Wills TA. Stress, social support, and the buffering hypothesis. Psychol. Bull. 1985. 98: 310-357.

Cohen S. Psychosocial models of the role of social support in the etiology of physical disease. Health Psychol. 1988. 7: 269-297.

Fornell C, Larcker DF. Structural Equation Models with Unobservable Variables and Measurement Error: Algebra and Statistics. Northwestern University. 1981.18: 382-388.

He SY. The social networks and life satisfaction of the lowincomeelderly living alone. Unpublished master' thesis. 2000. Seoul National University. Seoul.

Kim MK, Choi AR, Han GS, Jeong SG, Jeong MO, Kim DH, Ham, JS. Dairy products intake and managing diabetes. Korean J Dairy Sci Technol. 2011. 29: 17-22.

Kim SA, Park WS, Oh HC, Kang HY, Lee DH, Yi SW, Kwak, YH, Song JS. Prevalence and management status of diabetes mellitus in Korea . Korean Journal of Medicine. 2005. 68: 10-17.

Kim YS, Won CW, Choi HR, Kim BS. An Analysis of Original
Articles Targeting the Elderly Published by Korean Medical Doctors in 2007. J Korean Geriatr Soc. 2008. 12: 11-14.

Klein R, Klein BE, Moss SE, Davis MD, DeMets DL. The Wisconsin epidermiologic study of diabetic retinopathy. III. prevalence and risk of diabetic retinopathy when age at diagnosis is 30 or more years. Arch Opthalmol. 1984. 102: 527-532.

Lewis MA, Rook KS. Social control in personal relationships: Impact on health behaviors and psychological distress. Health Psychol. 1999. 18: 63-71.

Ryu JS, Kim SD, Park JS, Lee JS. Risk Factors of Impaired Fasting Glucose and Type 2 Diabetes Mellitus- Using Datamining Korean Journal of Epidemiology. 2006. 28: 138-151.

Uchino BN, Cacioppo JT, Kiecolt-Glaser JK. The relationship between social support and physiological processes: A review with emphasis on underlying mechanisms and implications for health. Psychol. Bull. 1996. 119: 488-531.

Van Dam HA, van der Horst FG, Knoops L, Ryckman RM, Crebolder HF, van den Bome BH. Social support in diabetes: a systematic review of controlled intervention studies. Patient Education and Counseling. 2005. 59: 1-2.

Wen CP, David Cheng TY, Tsai SP, Chan HT, Hsu HL, Hsu CC, et al. Are Asians at greater mortality risks for being overweight than Caucasians? Redefining obesity for Asians. Public Health Nutr. 2009. 12: 497-506.

Winocour PH. Effective diabetes care: a need for realistic targets. Br Med J. 2002. 324: 1577-1580.

https://doi.org/10.15616/BSL.2019.25.4.357

Cite this article as: Kang YJ, Park SN, Yoon KN. Structural Equation Analysis of Social Support, Impaired Fasting Glucose, and Type 2 Diabetes. Biomedical Science Letters. 2019. 25: 357-366. 